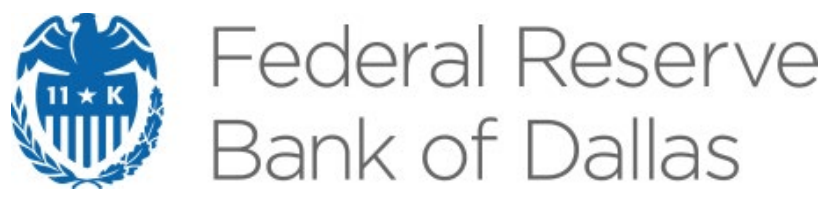

\title{
Making Sense of Increased Synchronization in Global House Prices
}

\author{
John V. Duca
}

Forthcoming in: Duca, John V. (2020), "Making Sense of Increased Synchronization in Global House Prices," Journal of European Real Estate Research.

\section{Working Paper 1911}

Research Department https://doi.org/10.24149/wp1911

Working papers from the Federal Reserve Bank of Dallas are preliminary drafts circulated for professional comment. The views in this paper are those of the authors and do not necessarily reflect the views of the Federal Reserve Bank of Dallas or the Federal Reserve System. Any errors or omissions are the responsibility of the authors. 


\title{
Making Sense of Increased Synchronization in Global House Prices*
}

\author{
John V. Duca ${ }^{\dagger}$
}

October 9, 2019

\begin{abstract}
Evidence indicates that house prices have become somewhat more synchronized during this century, likely reflecting more correlated movements in long-term interest rates and macroeconomic cycles that are related to trends in globalization and international portfolio diversification. Nevertheless, the trend toward increased synchronization has not been continuous, reflecting that house prices depend on other fundamentals, which are not uniform across countries or cities. Theory and limited econometric evidence indicate that the more common are fundamentals, the more in-synch house price cycles will become and the more substitution effects may matter. In addition, real estate markets that are open to immigration and foreign investment have become more sensitive to shifts in the international demand for property by migrants or investors.
\end{abstract}

JEL Codes: R20, R0

Keywords: House prices, synchronization, star cities, international capital flows

*I thank Joachim Montezuma and Martin Hoesli for helpful early input. The paper also reflects many insights from my collaboration with John Muellbauer and Anthony Murphy on several previous papers. Views and errors are those of the author and are not necessarily those of the Federal Reserve Bank of Dallas or the Federal Reserve System.

†John V. Duca, Oberlin College, jduca@oberlin.edu and Federal Reserve Bank of Dallas, john.v.duca@dal.frb.org. 


\section{Introduction}

Recent research has found that international house price cycles have become somewhat more synchronized since the early 2000s, and a short-horizon chart of real house prices would suggest this (see Figure 1). Miles (2017) finds that national house price appreciation rates have become more synchronized to a statistically significant, but small degree. Using deviations of house prices from their long-run trends (and similarly for major international metros), Alters, et al. (2018) uncovers a stronger increase in synchronization, with substantial controls for other factors. Related studies find that house prices have also become more sensitive to shifts in international capital flows and global liquidity conditions. These patterns likely reflect more correlated movements in long-term interest rates and macroeconomic cycles stemming from trends

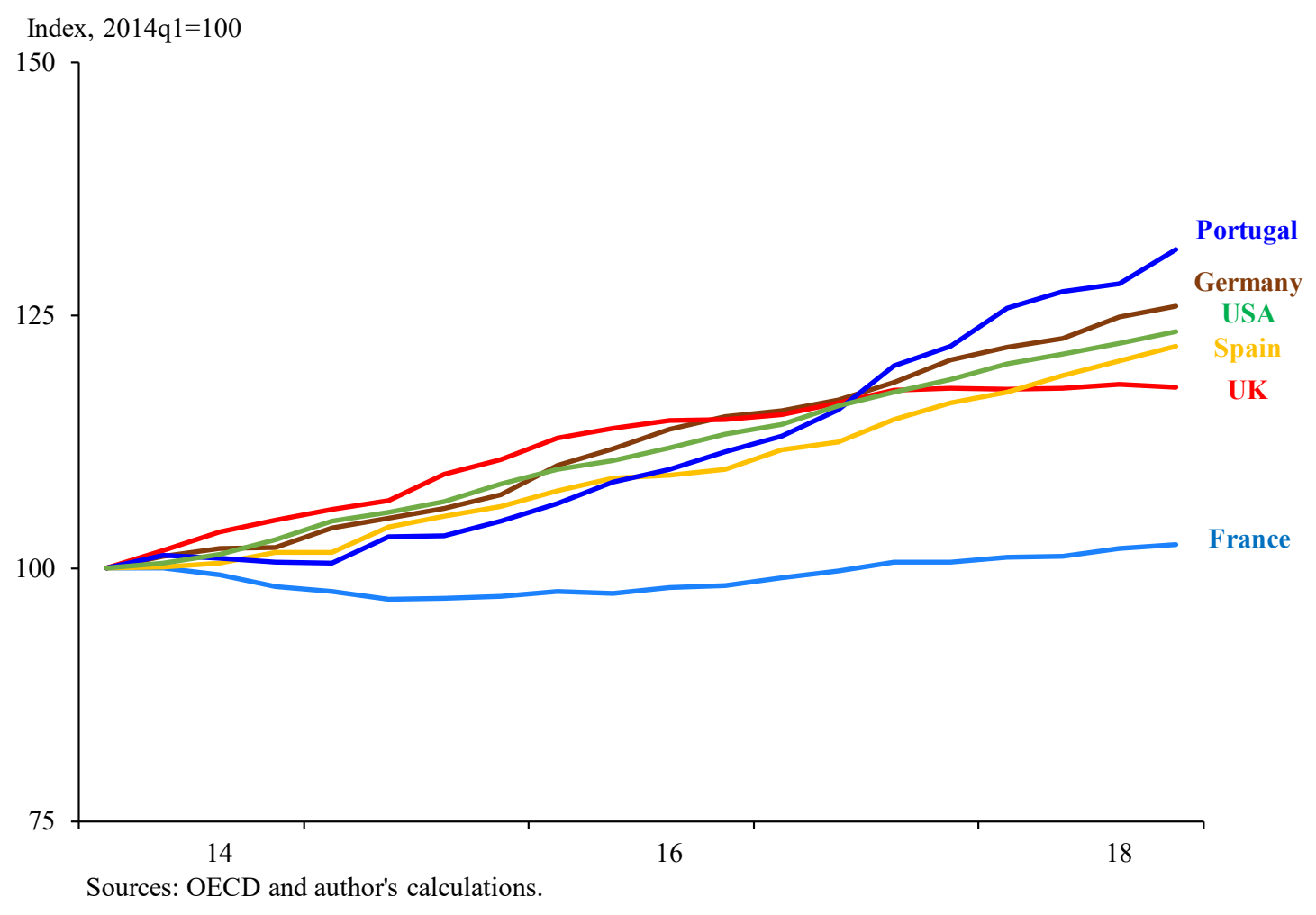

Figure 1: Real House Prices Highly Correlated for Many Western Economies Since 2014 
in globalization, migration, and international portfolio diversification. Together, these studies suggest that there may be less scope for diversifying real estate portfolios across national borders.

Nevertheless, it is important not to over-interpret these changes and to account for important distinctions in international house price patterns. Indeed, the trend toward increased synchronization has not been continuous, reflecting that house prices are driven by other fundamentals that are not uniform across areas. Theory and limited evidence from Alters, et al. (2018) indicate that the more common are fundamentals, the more synchronized are house price deviations from trend and the more substitution across areas matters. In addition, this study finds that property markets, which are open to immigration and foreign investment, have become more sensitive to shifts in the international demand for property by migrants or investors.

Another important caveat is that while there is stronger evidence that house price deviations from trend have become more synchronized, we should not ignore divergences in long-run trends in house prices. Indeed, focusing on co-movement in national appreciation rates during particular periods (see Figure 2), can overlook how such movements may unwind and that substantial deviations across the levels of real national house prices can emerge, as in the boom before the Great Recession and the bust that followed (see Duca, et al., 2019 and Figure 2). From a portfolio perspective, long-run trends matter for long-run investments in illiquid real estate assets.

\section{Drivers of House Price Cycles}

A basic supply and demand framework for modeling house prices arises by inverting the demand for housing services (Poterba, 1984). This approach implies that house prices are positively related to permanent income (which bolsters demand) and are negatively related to factors restraining the effective demand for housing, particularly the user cost of housing and the 


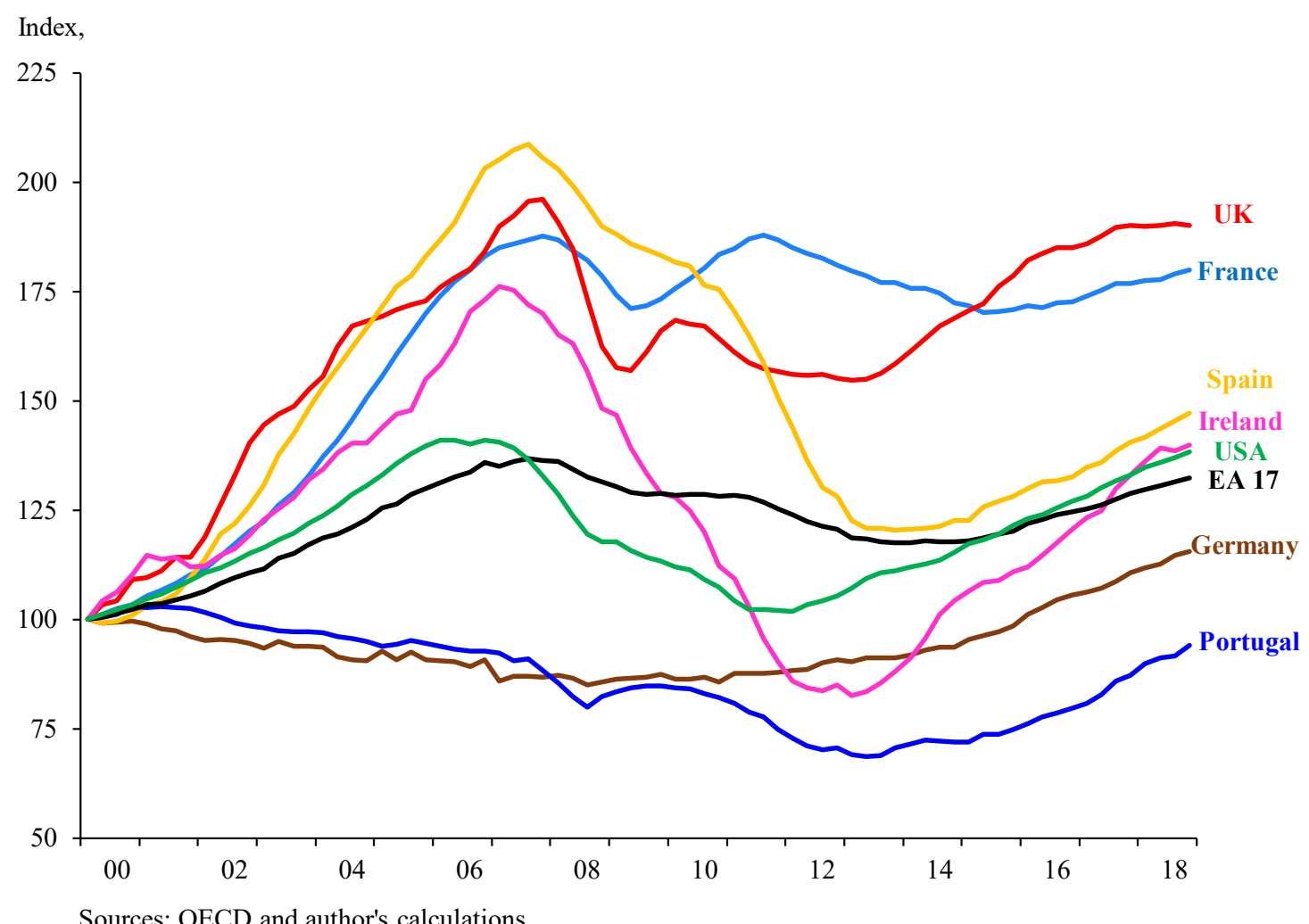

Sources: OECD and author's calculations.

Figure 2: Real House Prices Not Highly Correlated Across Many Economies Since 2000

stringency of credit constraints (inter alia, Duca, Muellbauer, and Murphy, 2011, and Mian and Sufi, 2009). In addition, prices are also negatively related to the price elasticity of housing supply (Glaeser, Gyourko, and Saiz, 2008, Gyourko, Saiz, and Summers, 2008, and Saiz, 2007 and 2010), which affects their sensitivity to shifts in demand. Because supply inelasticity amplifies the impact of demand shocks on the magnitude of house price cycles, the extent of synchronicity in house price cycles can be reduced by variation in the supply sensitivity to house prices across areas.

Indeed, studies of U.S. metro markets find strong evidence for these patterns and also that there are stronger long-run upward trends in house-price-to-rent ratios in less supply elastic areas, as shown in Figure 3, modified from Duca, Muellbauer, and Murphy (2019). Shortages of buildable lots in inelastic areas reflect zoning and geographical constraints, with upward long-run 


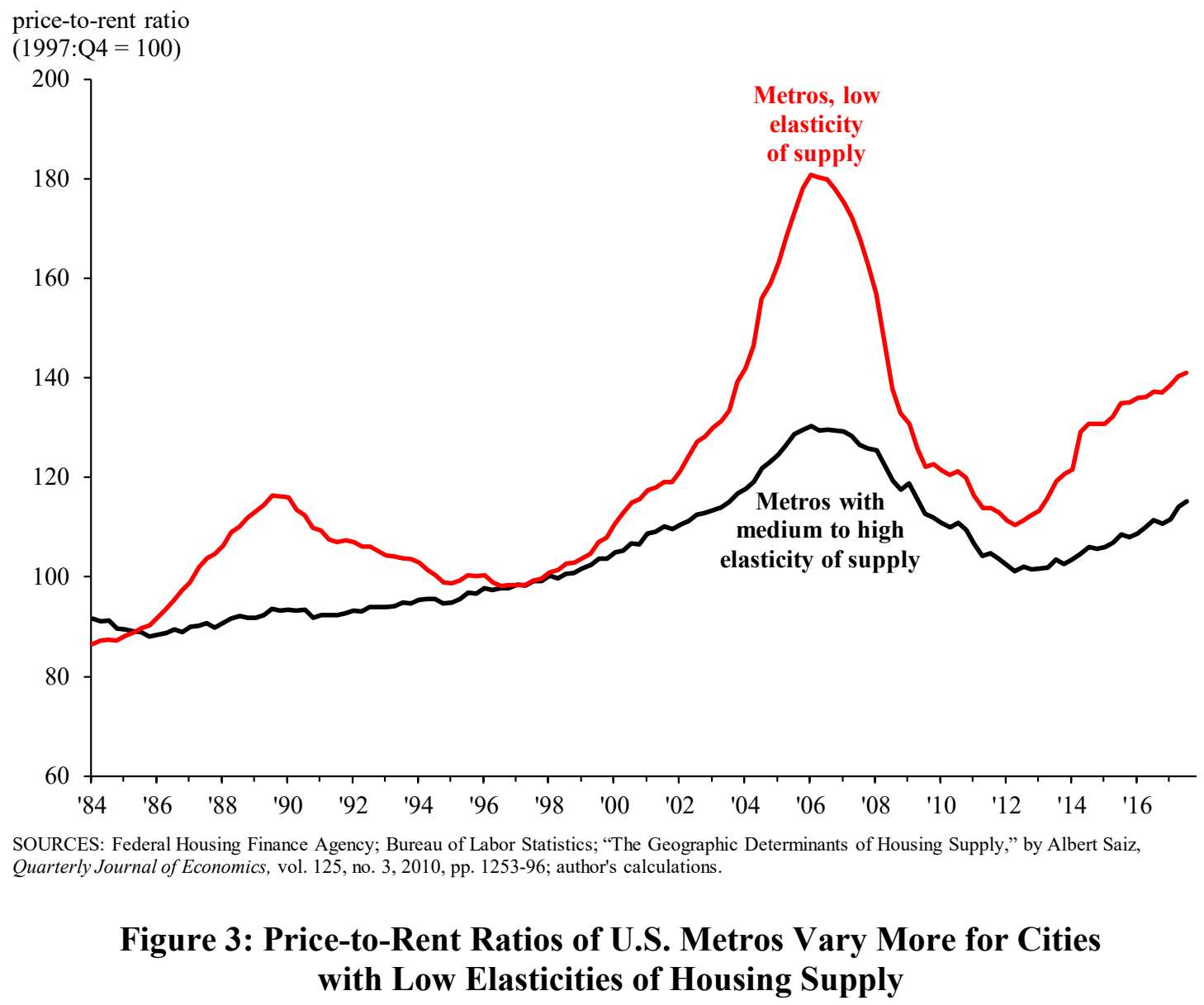

trends in real house prices owing mainly to the land component of prices with much less notable differences in the cost of the reproducible structure component of prices. An important implication is that house prices tend to be more correlated within groups of markets with more similar supply elasticities.

Among demand influences of house prices is permanent income. As business cycles have become more synchronized, so have incomes across advanced economies. Nevertheless, we have still seen recent large divergences in income across countries (as in Europe) and within countriesfor example, across “superstar" and other U.S. cities (Gyourko, Mayer, and Sinai, 2013).

Another major demand driver of house prices is the real user cost of capital, which is usually defined as the after-tax mortgage interest rate minus expected house price appreciation 
plus depreciation and insurance costs. ${ }^{1}$ The interest rate component has become more synchronized across countries since the 1980s - as illustrated in Figure 4 reproduced with permission from Del Negro, et al., (2019). Furthermore, there is a high degree of co-movement in international interest rates, particularly long term interest rates (see Caceres, et al. (2016)), which are more relevant for the valuation of long-lived assets like housing. This reflects not only the post-1990 convergence of interest rates within Europe, but also the increased synchronization of international business cycles, the related adoption of more uniform monetary policy goals and tactics across major central banks, and a related increase in asset substitution among the sovereign debt of highly-rated nations.

\section{Real Interest Rate Trends Have Converged across Countries since the $1980 \mathrm{~s}$}

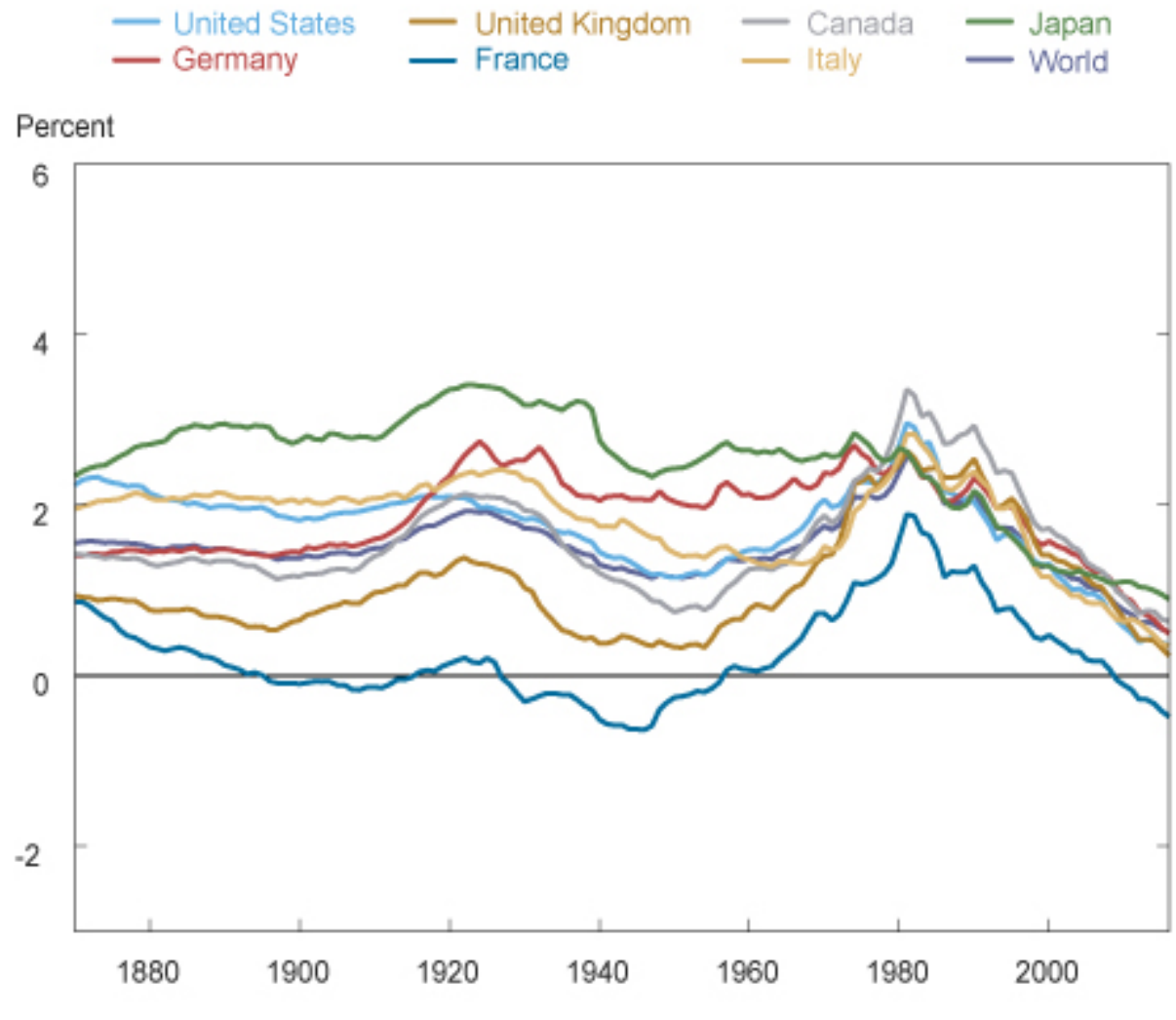

Source: Authors' calculations

${ }^{1}$ The last two components tend to be more uniform across areas and over time, though climate change may alter this. 


\section{Figure 4: Real Interest Rate Convergence}

(Source and Reproduced from: Del Negro, et al. (2019))

The second major component of user cost is the expected rate of real house price appreciation. Studies have increasingly found that such expectations tend to be formed with a good deal of extrapolation of past, observed appreciation (see Barberis, et al., 2018). The presence of substantial housing transactions costs can give rise serial correlation in excess returns, which implies momentum in property returns, which, in turn, can affect the formation of price expectations. Indeed, John Muellbauer and his various co-authors have found that using the average annual rate of appreciation over the prior four years yields a real user cost measure, which, along with other factors, outperforms other user cost measures in modeling house price movements in a number of countries (Australia, Canada, France, Germany, Ireland, the UK, and the U.S.) As a result, the impact of shocks to income and nominal mortgage rates can be amplified. For example, all else the same, a decline in nominal interest rates would directly lower the user cost, which would at some point further indirectly lower it by increasing the expected rate of home price appreciation. This pattern implies that if nominal mortgage rates and income have become more synchronized, their initial impact on house prices is amplified by expectations.

Controlling for housing supply and user costs generally explains house prices in many countries with stable credit conditions, but not for those experiencing credit liberalizations or shifts in mortgage credit standards that affect the nonprice terms of credit for potential homebuyers. There is an emerging consensus that countries where credit standards weakened during the early 2000s boom, suffered larger swings in house prices and construction relative to their past and to other countries. Examples include the U.S. and Ireland (Figure 5), which saw large rises in LTVs and mortgage debt-service burdens among first-time homebuyers. De facto easings of credit standards also matter. For example, in Spain some lenders used over-inflated house appraisals to 
circumvent an 80 percent LTV cap on mortgages to be eligible for lenders to fund by issuing covered bonds. In addition, less well-regulated Spanish lenders-mainly cajas-tended to make riskier loans. While differences in credit systems also affect house prices and their international correlations, the international adoption of Basel III regulations has lessened the international variation and pro-cyclicality of mortgage credit standards, and thus, may tend to increase synchronization, on balance. Also working in this direction are new regulations that induce lenders to rely on more stable sources for funding mortgages. Interestingly, in the three countries that had seen looser credit standards in the mid-2000s boom, real house prices did not surge much beyond the EA-17 average during the recovery, perhaps reflecting, in part, the more prudent and harmonized regulatory era under Basel III.

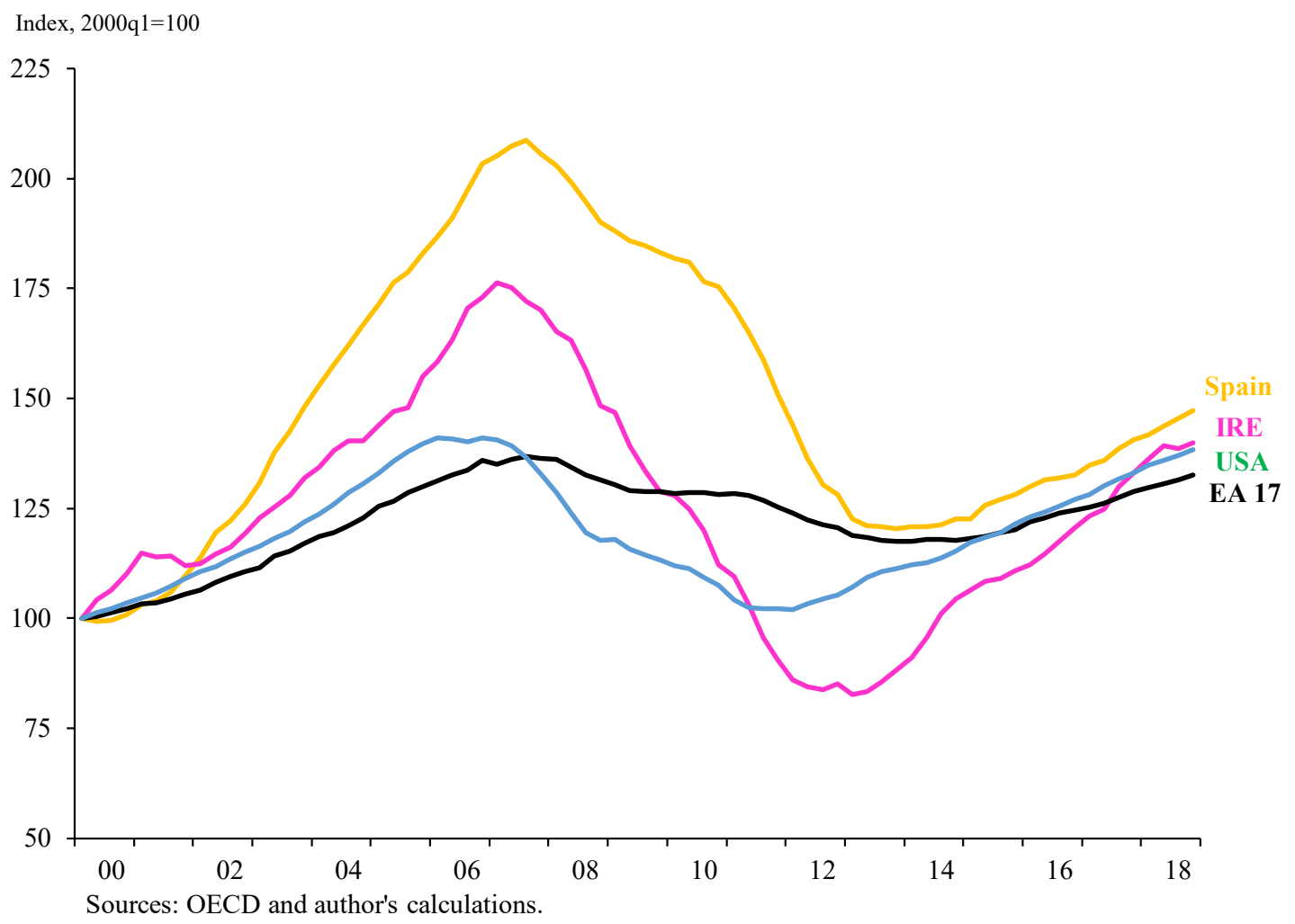

Figure 5: Real Price Booms and Busts in Nations With Somewhat Elastic Housing Supply 


\section{and Large Swings in Effective Loan Standards}

\section{Other Drivers of House Prices}

Metro house price studies have found strong correlations between city attributes and house prices (e.g., Cragg and Kahn, 1999, and Gyourko and Tracy, 1991). In the U.S., there is a strong tendency for price appreciation to be faster in cities with better amenities (e.g., more pleasant climate) and limited supply. Some of the link between house prices and less elastic housing supply may confound the demand to leave near waterfronts with the geographic constraints that impede building in coastal areas as Davidoff (2013) has stressed.

House prices are also affected by other fundamentals such as changes in property rights, immigration, and investment. Amid global financial integration, international investors have widened regional divergence in house prices within some nations and created important international spillovers (Cesa-Bianchi, Ferrero, and Rebucci (2018)). In their cross-country study, Cerutti, Dagher, and Dell'-Ariccia (2017) find that real exchange rate appreciations - and to a lesser extent current account deteriorations - are linked to credit booms that are positively linked to house price booms. As in Tillmann (2013), Cesa-Bianchi, Cespedes, and Rebucci (2015) findusing more countries and a measure of global liquidity more exogenous than capital flows — that global liquidity shocks affect house prices more in emerging than in advanced economies.

For example in 2012, many controls on rents were lifted in Portugal, which also became the

first country within the EA-17 to adopt a nationally tailored "Golden Visa" program providing preferential immigration treatment for those meeting investment criteria. Along with the appeal of low tax rates on foreign generated income, such reforms have induce notable increases in investment by migrants and foreign investors in Portugese properties (see Montezuma and McGarrigle, 2018). Before these changes, house prices in Portugal tended to lag behind those in 
most other European countries, notably Spain, over long periods. But since then, appreciation has tended to be relatively stronger in Portugal, reflecting stronger increases in the present values of rental cash flows and greater international capital inflows into property markets by seasonal and full-year migrants (Figure 6).

House price appreciation will likely be rapid for several years following such regime shifts as prices adjust upward toward higher equilibrium values, and will thereafter likely slow toward the average pace seen in benchmark countries or cities. Some recent research finds that expectations formation for real estate is not consistent with the implications of rational expectations in markets with low transactions costs and thick trading. Substantial transactions costs and thinness in the trading of real estate generate serial correlation - if not cycles - in excess returns. This, in turn,

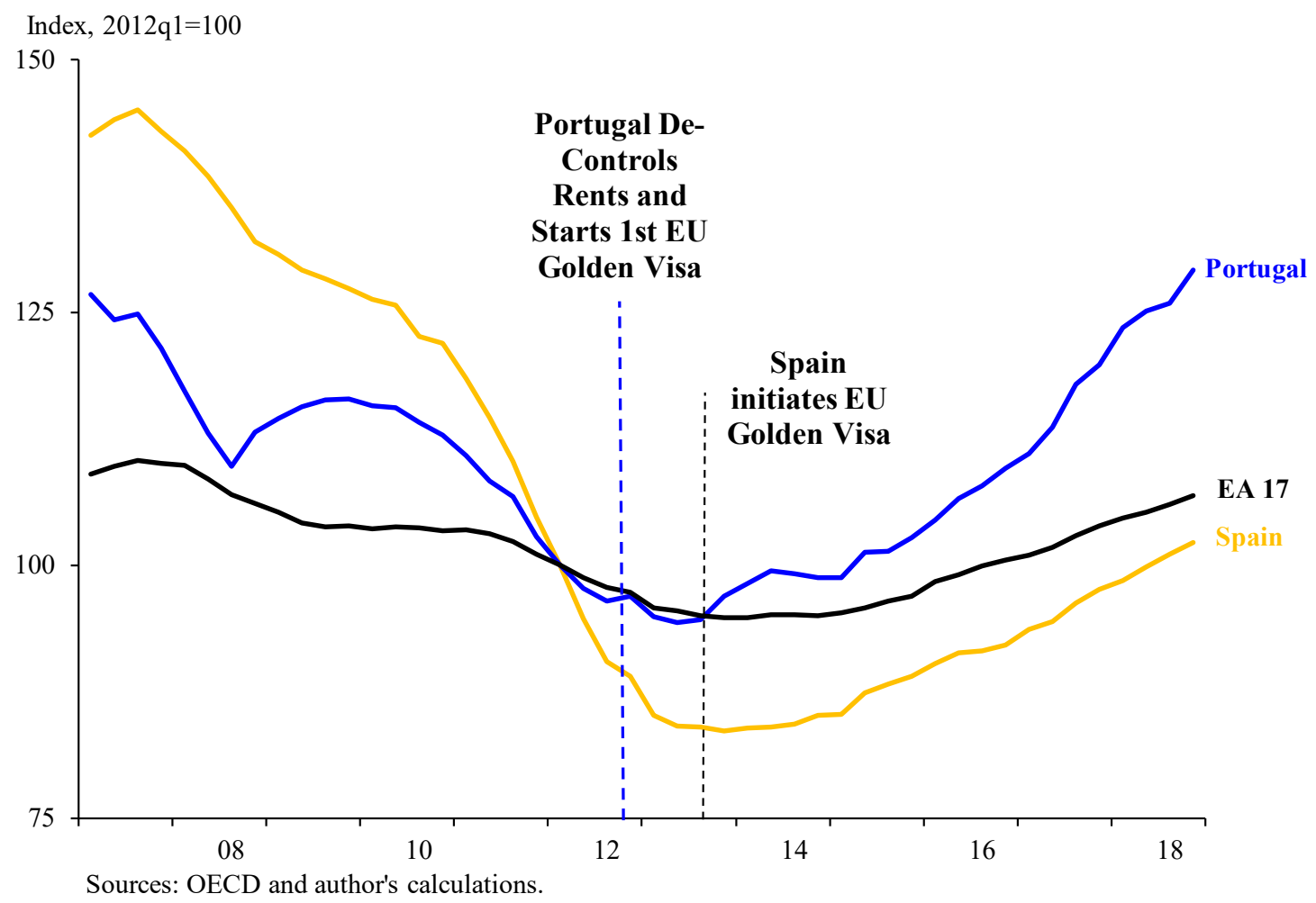

Figure 6: Portugese Real House Prices Outstrip EA-17 Prices Since the 2012 Reforms 
can induce momentum in real estate returns that induces some agents to form expectations that deviate from rational expectations in a perfect no frictions world. With momentum affecting expectations, the real user cost of real estate can experience a notable cycle following a shock. For this reason, a structural shift in housing or immigration policy that boosts property investment can induce a boom in house prices that may overshoot on the upside during an initial upswing that may partially reverse when the transition ends. ${ }^{2}$

From an investment perspective, one caution is that owing to the rarity of such changes, experience does not offer precise guidance about when such different phases occur. On the other hand, large transactions costs and inertia in immigration suggest that such transitions could last for a number of years and that transitions may span more than one upside cycle. This has occurred in a handful of metros that have joined or are in the process of joining the international club of “gateway" or "superstar" cities.

While housing policy reforms offer the potential for upside investment gains, shifts in policy could also work the other way. Many gateway and rising cities have experienced substantial appreciation owing to a combination of low housing supply elasticity and upward pressures on housing demand from faster income growth in highly educated or tech-oriented cities, plus high in-migration and capital inflows from other areas. On the other hand, the sizable declines in housing affordability for native populations and increasing congestion have created backlashes against foreign investment or immigration in some areas. Examples include pressures to limit immigration (which may have played a role in the Brexit vote) and the imposition of restrictions on foreign purchases of homes (e.g., recent restrictions in New Zealand), which can temper house

\footnotetext{
${ }^{2}$ See Abraham and Hendershott (1996) for a seminal paper documenting the existence of large booms and busts in metro house prices.
} 
price appreciation. Indeed, house prices in London stopped rising relative to those in other major European cities after the Brexit referendum (Figure 7). ${ }^{3}$

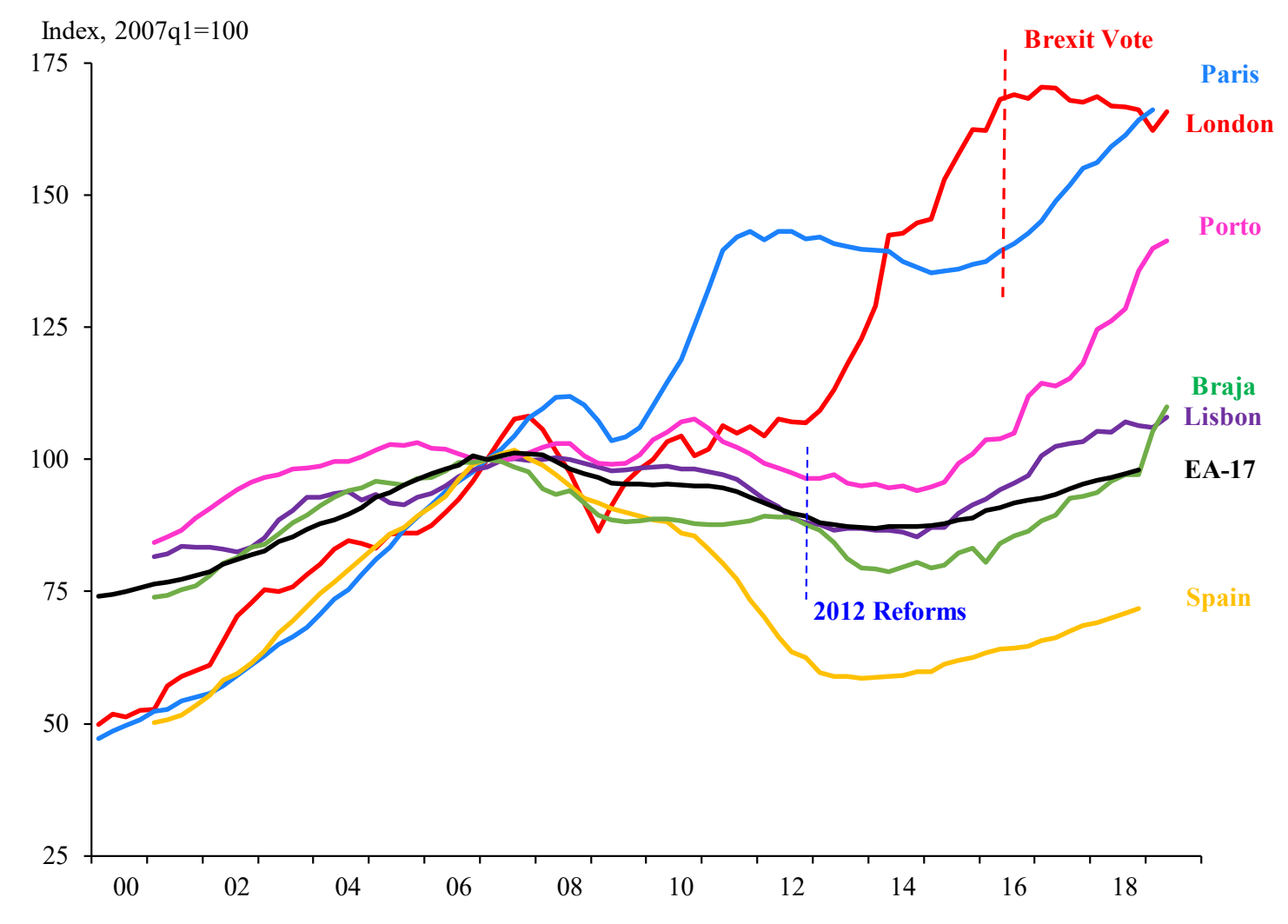

Figure 7: Removing Versus Imposing Barriers to Foreign Homeowners

\footnotetext{
${ }^{3}$ There are several options for addressing lower affordability and increased congestion. On the one hand, slowing immigration can limit upward price pressures from housing demand, but it may also make areas less vibrant and dynamic. Imposing rent controls may provide some short-run relief to incumbent renters but at the cost of reducing incentives to build new properties, which can undermine the long-run health of the rental market. On the other hand, better supply policies could help address affordability in a more efficient and market-oriented way. Well-designed combinations of policies to increase the supply elasticity of housing and improve public transportation can stem declines in affordability while helping to address climate change and congestion. Accompanying policies that increase access to higher education and smart technology can also bolster income growth and ameliorate inequality. A welldesigned mix of investment in public transport and education, sustainable zoning reforms, and opportunities for private investment offer the opportunity to restructure many cities and extend urban revitalization outside the current set of gateway cities.
} 


\section{Conclusion}

Changes in the degree to which house price cycles are internationally synchronized stem from variation in two categories of key drivers of house prices. The first are traditional fundamentals that affect the supply of and the demand for housing. The second include not only international capital flows that affect the synchronization of interest rates, but also property investment and immigration that more directly affect house prices. Both sets of factors are sensitive to the economic environment and public policy. Increased synchronization of business cycles, the Euro currency union, and more common monetary policy strategies and tactics have fostered an increase in the correlation of real interest rates across countries, which tend to increase the synchronization of international house prices. These effects can be amplified by the tendency for property owners to use extrapolative expectations of future house prices.

Controlling for supply factors, further portfolio flows might help, over time, reduce large property price differentials across Europe if there is a continuation of long-run trends toward 1) increased substitutability of top-rated sovereign debt, 2) increased economic integration in Euroarea, and 3) the adoption and maintenance of sensible mortgage credit standards and regulation. That said, it is important to recognize that owing to large transactions costs, high durationinvestments in property should focus on long-run prospects. Furthermore, despite the rise of globalization and the adoption of new technologies, we have seen substantial divergences in house prices emerge across gateway cities and metros in less vibrant areas within countries. These reflect not only the impact of stronger income and population in more tech, educated, and global oriented cities, but also changes in the demand for amenities toward more culturally appealing cities, often - but not exclusively in — warmer or coastal areas where the supply elasticity of housing is often limited. Further complicating investment decisions are potential shifts in housing or immigration policy that can notably affect the demand for housing. 
For all of these reasons, shifts in prospective returns and the synchronization of international returns on property depend on more than just an arbitraging away of general property price differentials. They also depend on underlying factors that can drive those differentials. Simple correlations and changes in those correlations do not do away with the need for careful analysis of property investment, and if anything, warrant analysis of both how and why we may observe changes in the extent to which international house prices are synchronized. 


\section{References}

Abraham, Jesse M. and Patric H. Hendershott. 1996. "Bubbles in Metropolitan Housing Markets.” Journal of Housing Research 7 (2): 191-207.

Alter, Adrian, Jane Dokko, and Dulani Seneviratne. 2018. "House Price Synchronicity, Banking Integration, and Global Financial Conditions.” IMF Working Paper WP/18/215. https://doi.org/10.5089/9781484385692.001

Barberis, Nicholas, Robin Greenwood, Robin, Lawrence Jin, and Andrei Shleifer. 2018. "Extrapolations and Bubbles." Journal of Financial Economics 129 (2): 203-227. https://doi.org/10.1016/j.jfineco.2018.04.007

Caceres, Carlos, Yan Carrière-Swallow, Ishak Demir, and Bertrand Gruss. 2016. "U.S. Monetary Policy Normalization and Global Interest Rates.” IMF Working Paper WP/16/195. https://doi.org/10.5089/9781475543056.001

Cerutti, Eugenio, Jihad Dagher, and Giovanni Dell'Ariccia. 2017. “Housing Finance and Real Estate Booms: A Cross-Country Perspective.” Journal of Housing Economics 38: 1-13. https://doi.org/10.1016/j.jhe.2017.02.001

Cesa-Bianchi, Ambrogio, Luis Felipe Cespedes, and Alessandro Rebucci. 2015. "Global Liquidity, House Prices, and the Macroeconomy: Evidence from Advanced and Emerging Economies." Journal of Money, Credit, and Banking 47 (S1): 301-35. https://doi.org/10.1111/jmcb.12204

Cragg, Michael I. and Matthew E. Kahn. 1999. “Climate Consumption and Climate Pricing from 1940 to 1990." Regional Science and Urban Economics 29 (4): 519-39. https://doi.org/10.1016/s0166-0462(98)00046-5 
Davidoff, Thomas. 2016. "Supply Factors Are Not Valid Instrumental Variables for Home Prices Because They Are Correlated With Many Demand Factors." Critical Finance Review 5 (2): 177-206. https://doi.org/10.1561/104.00000037

Del Negro, Marco, Domenico Giannone, Marc Giannoni, Andrea Tambalotti, Brandyn Bok, and Eric Qian. 2019. “Global Trends in Interest Rates.” Federal Reserve Bank of New York Liberty Street Economics, February 27, 2019.

Duca, John V., John Muellbauer, and Anthony Murphy. 2010. "Housing Markets and the Financial Crisis of 2007-2009: Lessons for the Future.” Journal of Financial Stability 6 (4): 203-17. https://doi.org/10.1016/j.jfs.2010.05.002

Duca, John V., John Muellbauer, and Anthony Murphy. 2019. "What Drives House Price Cycles? International Experience and Policy Issues.” Manuscript in process.

Glaeser, Edward L., Joseph Gyourko, and Albert Saiz. 2008. "Housing Supply and Housing Bubbles." Journal of Urban Economics 64 (2): 198-217. https://doi.org/10.1016/j.jue.2008.07.007

Gyourko, Joseph, Christopher Mayer, C. and Todd Sinai. 2013. "Superstar Cities." American Economic Journal: Economic Policy 5 (4): 167-199. https://doi.org/10.1257/pol.5.4.167

Gyourko, Joseph, Albert, Saiz, A. and Summers, Anita A. 2008. "A New Measure of the Local Regulatory Environment for Housing Markets: The Wharton Residential Land Use Regulatory Index.” Urban Studies 45 (3): 693-729. https://doi.org/10.1177/0042098007087341

Gyourko, Joseph, and Joseph Tracy. 1991. "The Structure of Local Public Finance and the Quality of Life.” Journal of Political Economy 99 (4): 774-806. https://doi.org/10.1086/261778 
Mian, Atif and Amir Sufi. 2009. "The Consequences of Mortgage Credit Expansion: Evidence from the U.S. Mortgage Default Crisis." Quarterly Journal of Economics 124 (4): 1449-96. https://doi.org/10.1162/qjec.2009.124.4.1449

Miles, William. 2017. "Has There Actually Been a Sustained Increase in the Synchronization of House Price (and Business) Cycles Across Countries?” Journal of Housing Economics 36: 25-43. https://doi.org/10.1016/j.jhe.2017.02.002

Montezuma, Joaquim and Jennifer McGarrigle. 2019. "What Motivates International Homebuyers? Investor to Lifestyle 'Migrants' in a Tourist City.” Tourism Geographies 21 (2): 214-234. https://doi.org/10.1080/14616688.2018.1470196

Poterba, James. 1984. "Tax Subsidies to Owner-Occupied Housing: An Asset-Market Approach.” Quarterly Journal of Economics 99 (4): 729-52. https://doi.org/10.2307/1883123

Saiz, Albert. 2007. "Immigration and Housing Rents in American Cities." Journal of Urban Economics 61 (2): 345-71. https://doi.org/10.1016/j.jue.2006.07.004

Saiz, Albert. 2010. “The Geographic Determinants of Housing Supply.” Quarterly Journal of Economics 125 (3): 1253-96. https://doi.org/10.1162/qjec.2010.125.3.1253 